\title{
TANGGAPAN PERUSAHAAN TERHADAP KOMPETENSI MAHASISWA JOB TRAINING JURUSAN ADMINISTRASI NIAGA POLITEKNIK NEGERI JAKARTA \\ Tuti Hartati ${ }^{1)}$, Mawarta Onida Sinaga ${ }^{2)}$, Amanda Fidienna dan Inna Sifatun Nazah Jurusan Administrasi Niaga Politeknik Negeri Jakarta \\ Email:.1uti.hartati@yahoo.co.id ,2ㅍwaronida@yahoo.com
}

\begin{abstract}
The Influence of Celebrity Brand Ambassador Credibility against Wardah's Purchase Decision. Wardah ad version of Dewi Sandra. Economics and Business Faculty. State Islamic University of Syarif Hidayatullah Jakarta 2017. This study aims to determine and analyze the influence of the credibility of Dewi Sandra as a celebrity brand ambassador against consumer purchasing decisions on Wardah cosmetic products. The research method used is quantitative research method. The results of the analysis are presented in the form of numbers then explained and interpreted in a description. There are 100 samples used in this study, which is a student of Faculty of Economics and Business. State Islamic University Syarif Hidayatullah Jakarta who had bought and used Wardah beauty products. In this research used 2 variables namely credibility brand ambassador as independent variable and purchase decision as dependent variable. Data analysis in this research use validity test, reliability test, normality test, linearity test and hypothesis test consisting of simple linear regression test, simple correlation test, coefficient of determination test (R2), and T significance test. Data processing in this research is assisted By SPSS version 24.00 for windows. The results of this study indicate on the simple correlation test (R2) that brand ambassador credibility has an influence of $25.9 \%$ on purchasing decisions, while the remaining $74.1 \%$ of consumer purchasing decision making process influenced by other variables not examined in this study .
\end{abstract}

Keywords: brand ambassador credibility, purchase decision, Wardah

\section{Abstrak}

Pengaruh Kredibilitas Brand ambassador Selebriti terhadap Keputusan Pembelian produk Wardah. Iklan Wardah versi Dewi Sandra. Fakultas Ekonomi dan Bisnis. Universitas Islam Negeri Syaarif Hidayatullah Jakarta 2017. Penelitian ini bertujuan untuk mengetahui dan menganalisa pengaruh kredibilitas Dewi Sandra sebagai brand ambassador selebriti terhadap keputusan pembelian konsumen pada produk kosmetik Wardah. Metode penelitian yang digunakan adalah metode penelitian kuantitatif. Hasil analisis disajikan dalam bentuk angka-angka kemudian dijelaskan dan diinterpretasikan dalam suatu uraian. Terdapat 100 sampel yang digunakan dalam penelitian ini, yang merupakan mahasiswi Fakultas Ekonomi dan Bisnis. Universitas Islam Negeri Syaarif Hidayatullah Jakarta yang pernah membeli dan menggunakan produk kecantikan Wardah. Dalam penelitian ini digunakan 2 variabel yaitu kredibilitas brand ambassador sebagai variabel bebas dan keputusan pembelian sebagai variabel terikat. Analisis data pada penelitian ini menggunakan uji validitas, uji reliabilitas, uji normalitas, uji linearitas dan uji hipotesis yang terdiri dari uji regresi linear sederhana, uji korelasi sederhana, uji koefisien determinasi (R2), dan uji signifikansi $T$. Pengolahan data pada penelitian ini dibantu oleh program SPSS versi 24.00 for windows. Hasil penelitian ini menunjukkan pada uji korelasi sederhana (R2) bahwa kredibilitas brand ambassador

memiliki pengaruh sebesar 25,9\% terhadap keputusan pembelian, sedangkan sisanya yaitu 74,1\% proses pengambilan keputusan pembelian konsumen dipengaruhi oleh variabel-variabel lainnya yang tidak diteliti dalam penelitian ini.

Kata Kunci: Kredibilitas Brand Ambassador, Keputusan Pembelian, Wardah 


\section{PENDAHULUAN}

\section{Latar Belakang}

Kegiatan Job Training atau Praktek Kerja Lapangan (PKL) adalah salah satu syarat yang harus di jalani oleh Mahasiswa Program Studi Administrasi Bisnis Jurusan Administrasi Niaga Politeknik Negeri Jakarta. Kewajiban ini dilaksanakan oleh Mahasiswa setelah mereka lulusdari semester 5 .

Dasar hukum pelaksanaan PKL tertuang dalam Buku Pedoman Tugas Akhir Program Studi Administrasi Bisnis Tahun 2014, Bab II menyatakan bahwa PKL adalah Latihan Kerja yang dilakukan oleh Mahasiswa pada suatu lembaga atau instansi, baik instansi pemerintah maupun swasta. Kegiatan PKL ini dilaksanakan maksimal selama 3 bulan dan memiliki bobot 2 SKS.

Tujuan dilaksanakan PKL adalah agar:

1. Mahasiswa mampu membuat proposal PKL sesuai dengan mata kuliah Teknik Penulisan Laporan (TPL)

2. Mahasiswa mampu mengadakan studi perbandingan antar ilmu yang diperoleh di bangku perkuliahan dengan aplikasi di lapangan

3. Mahasiswa mampu meneliti dan menganalisis data untuk disusun dalam Laporan Tugas Akhir.

Prosedur pelaksanaan PKL adalah sebagai berikut:

1. Ketua Program Studi (KPS) memberikan informasi kepada mahasiswa tentang distribusi bidangbidang yang akan diobservasi

2. Mahasiswa mengajukan proposal kepada KPS sesuai dengan bidang yang dipilih

3. KPS menyeleksi bidang yang dipilih oleh mahasiswa agar sesuai dengan distribusi yang sudah ditetapkan

4. KPS menentukan dosen Pembimbing 1 dan Pembimbing 2

5. Mahasiswa meminta formulir permohonan PKL dan mendapat Surat Pengantar untuk ke Perusahaan
Dalam realitasnya ketika mahasiswa mendatangi keperusahaan, banyak perusahaan atau industri yang menolak dan tidak bersedia menerima mahasiswa yang akan melakukan PKL dengan berbagai alasan. Data yang tercatat pada Jurusan Administrasi Niaga bahwa dari jumlah mahasiswa tahun akademi 2011/2012, yang jumlahnya 150 orang, terdapat beberapa kasus atau masalah yang ditemui oleh mahasiswa, ketika mereka mendatangi keperusahaan untuk mendapatkan tempat melakukan PKL, ternyata sebagian dari mereka mendapat permasalahan dalam berbagai hal antara lain:

1. Perusahaan Tertutup

2. Kuota untuk PKL terbatas

3. Tidak sesuai dengan bidangnya

Kondisi Mahasiswa Semester 6 Kelas D Yang Sedang Melaksanakan PKL ke Perusahaan

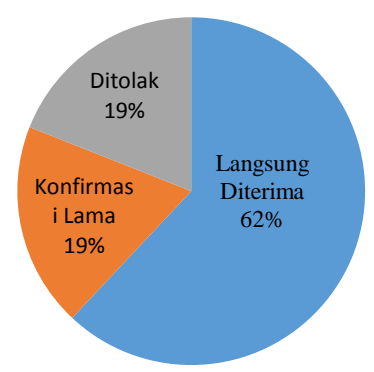

Diterima dengan Baik

- Perusahaan Tertutup

Kuota untuk PKL Terbatas

$\square$ Tidak Sesuai dengan Bidangnya

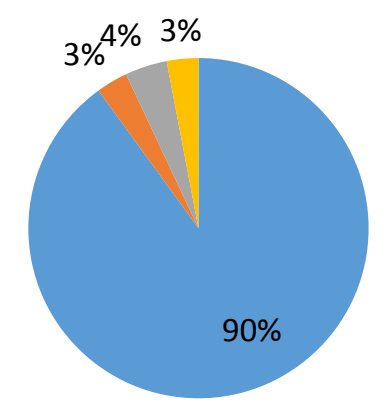


Masalah tersebut di atas, membuat sebagian mahasiswa menjadi lambat untuk mendapatkan tempat PKL dan mengakibatkan lama dalam proses penulisan dan berdampak pula terhadap lambatnya untuk mengikuti Jadwal sidang Tugas Akhir.

Kompetensi Mahasiswa Program Studi Administrasi Bisnis Jurusan Administrasi Niaga yang akan diteliti adalah mencakup 3 (tiga) hal, yaitu Pengetahuan (Knowledge), Keterampilan (Skill) dan Sikap atau Perilaku (Attitude). Pengujian Kompetensi diuji dengan menggunakan indikator kompetensi yang digunakan dalam proses monitoring atau pemantauan yang dilaksanakan oleh tim dosen peneliti yaitu dengan format yang mencakup 3 varibel :

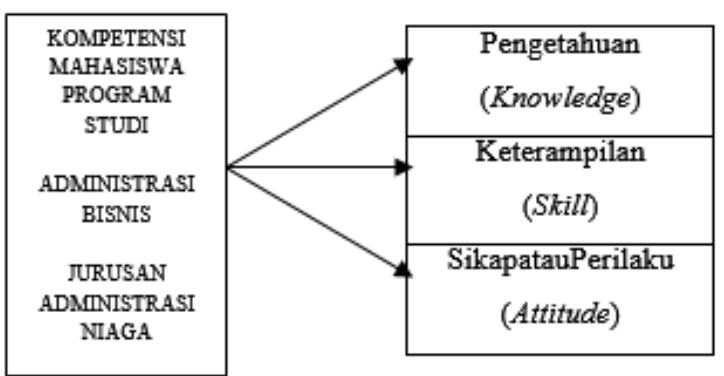

\section{Rumusan Masalah}

1. Bagaimana tanggapan perusahaan terhadap kompetensi mahasiswa Program Studi Administrasi Bisnis Jurusan Administrasi Niaga PoliteknikNegeri Jakarta ketika melaksanakan PKL?

2. Apa harapan perusahaan terhadap Program Studi Administrasi Bisnis Jurusan Administrasi Niaga Politeknik Negeri Jakarta?

\section{Tujuan Penelitian}

\section{Tujuan Umum}

Mengetahui tanggapan perusahaan terhadap kompetensi mahasiswa Program Studi Administrasi Bisnis Jurusan Administrasi Niaga Politeknik Negeri Jakarta ketika melaksanakan Job Training

\section{Tujuan Khusus}

1. Mengetahui kompetensi mahasiswa yang melakukan PKL.

2. Mengetahui harapan dan saran dari perusahaan terhadap Program Studi Administrasi Bisnis Jurusan AdministrasiNiagaPoliteknikNegeri Jakarta.

Sesuai dengan Visi dan Misi sertaTujuan Program Studi yang tertulis dalam Buku Pedoman Pendidikan Diploma Politeknik tahun 2010, bahwa mahasiswa Program Studi Administrasi Bisnis Jurusan Administrasi Niaga pada saat menjalani PKL, maka mereka akan mampu dan berkompeten melakukan halhal sebagai berikut:

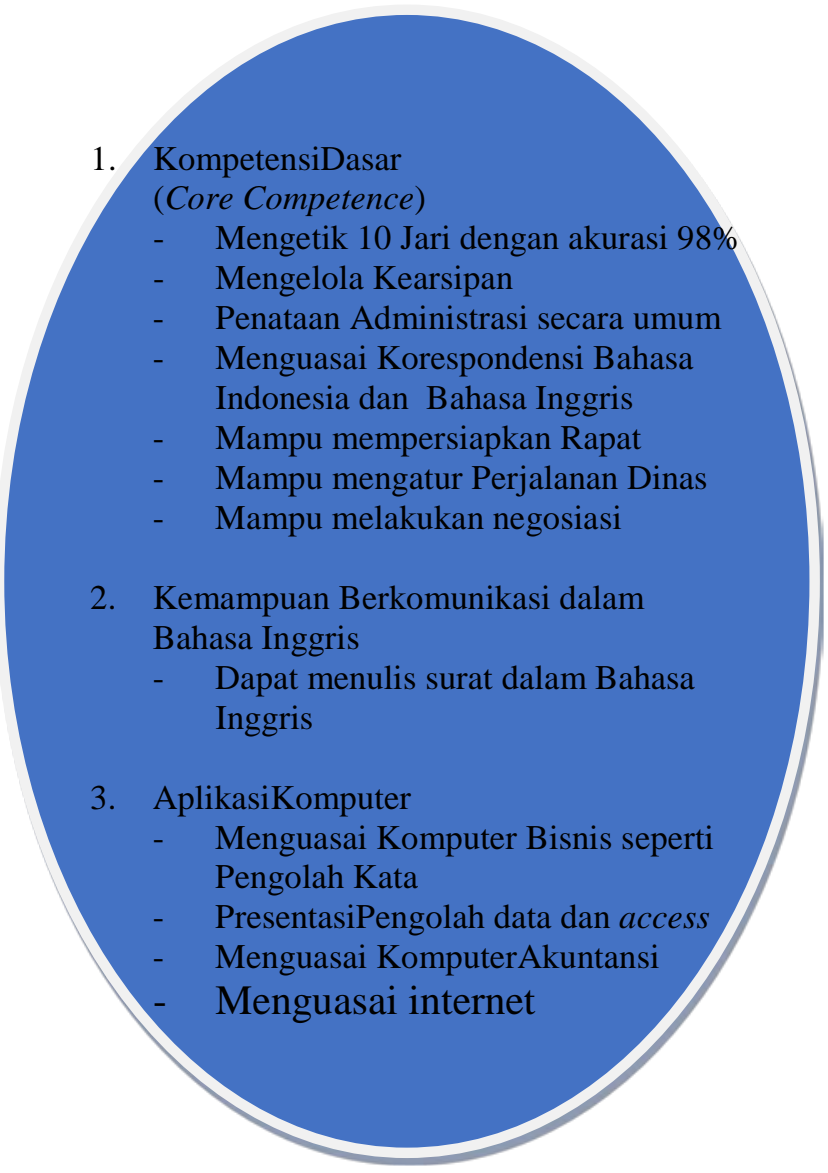

Sumber: Buku Pedoman Pendidikan Diploma Politeknik Tahun 2010 


\section{Manfaat Penelitian}

1. Mendapatkan data yang berupa tanggapan dan Penilaian beberapa perusahaan tentang Kompetensi mahasiswa Program Studi Administrasi Bisnis yang melakukan PKL.

2. Hasil penelitian ini juga berguna sebagai sumber informasi untuk melakukan perbaikan dan peninjauan ulang terhadap teknik pelaksanaan PKL yang adas aat ini.

\section{Tinjauan Pustaka}

Kompetensi adalah keahlian professional yang dimiliki oleh setia pprofesi sebagai hasil dari pendidikan formal, ujian professional maupun ke ikut sertaan dalam pelatihan intern dan ektern, seminar, symposium dan lainlain (Ida Suraida. Jurnal Sosiohumaniora, Vol. 7, No. 3 November 2005) Salah satu carauntuk mengembangkan pembelajaran di kelas, guru harus mampu dan mau mengembangkan kurikulum berbasis kompetensi. Adapun manfaat dalam pengukuran kompetensi adalah terampil berkomunikasi, mahir menganalisa, percaya diri, mampu bersaing, dan mampu mengerjakan.(Surjanti Jun. Jurnal Pendidikan. Volume 7, No. 2 September 2008).

Menurut Payaman J. Simanjuntak (2005:10) dijelaskan bahwa: "Kompetensi merupakan kemampuan dan keterampilan melakukan kerja.”

Gordon dalam bukunya: Kompetensi, konsep, karakteristik dan implementasi, mengatakan bahwa beberapa aspek yang terkandung dalam kompetensi adalah:

Pengetahuan (knowledge) yaitu kesadaran dalam bidang kognitif dan mengetahui cara melakukan tugasnya.

Pemahaman (understanding) yaitu memahami tentang apa yang dilayani.

Kemampuan (skills) yaitu sesuatu yang dimiliki (keterampilan) apa yang dimiliki seorang PR untuk melakukan tugasnya.

Nilai (value) yaitu standard perilaku yang telah dilayani atau telah menyatu dalam dirinya, misalnya: standard perilaku seorang petugas humas adalah well informed dan bersifat terbuka.

Minat (interest) yaitu kecenderungan seseorang untuk melakukan sesuatu pekerjaan.

Berdasarkan pemahaman kompetensi di atas, maka kata kunci kompetensi adalah kemampuan. Menurut pendapat Kartini Kartono (1998: 139-140) dijelaskan bahwa: "Kemampuan adalah segenap daya, kesanggupan, kekayaan, kecakapan, dan kekuatan yang terdapat pada individu untuk bertingkah aku, khususnya untuk bertingkah laku sebagai pemimpin.”

Kompetensi merupakan perpaduan dari pengetahuan, keterampilan, nilai dan sikap yang direfleksikan dalam kebiasaan berpikir dan bertindak.Kompetensi diartikan sebagai pengetahuan, keterampilan dan kemampuan yang dikuasai oleh seseorang yang telah menjadi bagian dari dirinya, sehingga dia dapat melakukan perilaku-perilaku kognitif, afektif, dan prikomotorik yang baik.Kurikulum Berbasis Kompetensi lebih menekankan pada kemampuan melakukan sesuatu yang berhubungan dengan kegiatan melakukan sesuatu. (Mulyasa, 2003:3)

\section{METODOLOGI PENELITIAN Desain Penelitian}

Desain penelitian yang digunakan dalam penelitian ini adalah deskriptif kualitatif. Pengambilan data dilakukan secara retrospektif bersumber dari kuesioner yang telah disediakan.

\section{Tempat dan Waktu Penelitian}

Penelitian dilakukan di perusahaanperusahaan yang telah bekerjasama dengan Program Studi Administrasi Bisnis Jurusan Administrasi Niaga Politeknik Negeri Jakarta dan menjadi tempat mahasiswa melakukan PKL periode Februari sampai dengan April 2017, seperti yang terlihatpada tabel 3.1.Adapun waktu penelitian yaitu April-Mei 2017. 
Tabel 1. Perusahaan TempatMahasiswa Job Training

\begin{tabular}{lll}
\hline No. & Nama Perusahaan & Lokasi \\
\hline 1 & PT. Pertamina & Jakarta \\
2 & BULOG & Jakarta \\
3 & Trakindo & Jakarta \\
4 & ANTAM & Jakarta \\
5 & Bank BNI & Jakarta \\
6 & Bank Indonesia & Jakarta \\
7 & PT. Garuda Indonesia & Jakarta \\
8 & United Tractor & Jakarta \\
9 & Sucofindo & Jakarta \\
10 & JasaMarga & Jakarta \\
11 & PT. Bayer & Jakarta \\
12 & PT. Holcim & Jakarta \\
\hline
\end{tabular}

\section{Subjek Penelitian}

Subjek penelitian ini adalah mahasiswa semester akhir Program Studi Administrasi Bisnis Jurusan Administrasi Niaga Politeknik Negeri Jakarta yang melaksanakan PKL pada Februari-April 2017.

\section{Populasi Penelitian}

Mahasiswa semester akhir Program Studi Administrasi Bisnis Jurusan Administrasi Niaga Politeknik Negeri Jakarta yang melaksanakan PKL pada Februari-April 2017.

\section{Besar Sampel}

Besar sampel dalam penelitian ini dihitung menggunakan rumus Slovin.Data jumlah populasi penelitian merupakan jumlah mahasiswa yang melakukan PKL periode Februari-April 2017 yaitu sebanyak 103 mahasiswa. Berikut perhitungannya:

$$
\begin{aligned}
& n=\frac{N}{1+N e^{2}} \\
& n=\frac{103}{1+103(0,1)^{2}} \\
& n=50,74
\end{aligned}
$$

Keterangan:

n : Jumlah minimal sampel

$\mathrm{N} \quad$ : Jumlah populasi

e : Tingkat kesalahan yang masih

dapat ditoleransi $=10 \%$
Berdasarkan perhitungan di atas, kuesioner yang diisi oleh supervisor dari subjek penelitian.

Jumlah minimal sampel adalah 50,74 yang dibulatkan menjadi 50,1 mahasiswa. Dari jumlah ini kemudian dibagi secara proporsi ke dalam empat kelas yang mengikuti PKL, sehingga jumlah minimal sampel yang diambil dari masing-masing kelas berjumlah 13 mahasiswa.

\section{Cara Pengambilan Sampel}

Sampel dipilih menggunakan teknik simple random sampling, yaitu sample dipilih secara acak dari masing-masing kelas hingga mencapai jumlah yang ditentukan.Sumber data berasal dari kuesioner penelitian yang diisi oleh masing-masing supervisor perusahaan yang mengawasi mahasiswa PKL.

\section{Instrumen, Cara Pengumpulan Data, dan Sumber Data}

Instrumen yang digunakan dalam penelitian ini berupa kuesioner. Cara pengumpulan data dengan cara penyebaran kuesioner kepada masing-masing supervisor dari mahasiswa yang menjadi subjek penelitian. Data yang diambil dalam penelitian ini bersumber dari kuesioner.

\section{HASIL DAN PEMBAHASAN}

Berikut ini adalah penjelasan mengenai tanggapan dan jawaban responden dalam hal ini supervisor perusahaan tempat mahasiswa Praktek Kerja Lapangan, terhadap Kompetensi mahasiswa Program Studi Administrasi Bisnis.

Berdasarkan kuesioner yang telah disebar kepada responden, maka peneliti menganalisi hasil kuesioner sebagai berikut: 


\begin{tabular}{|c|c|c|}
\hline Kemampuan & Beradaptasi & dengan \\
\hline Lingkungan & & \\
\hline Pernyataan & responden & tentang \\
\hline “Kemampuan & Beradaptasi & dengan \\
\hline Lingkungan”, c & apat dilihat pad & a Tabel 2. \\
\hline Tabel 2. Kemam & uan Mahasiswa & untuk \\
\hline Beradaptasi den & an Lingkungan & \\
\hline Kategori & Jumlah n=52 & Persentase \\
\hline Cukup Baik & 2 & 3,8 \\
\hline Baik & 4 & 7,7 \\
\hline Lebih dari & 20 & 38,5 \\
\hline Baik & & \\
\hline Istimewa & 20 & 38,5 \\
\hline Sangat & 6 & 11,5 \\
\hline Istimewa & & \\
\hline Jumlah & 52 & 100 \\
\hline
\end{tabular}

Berdasarkan tabel di atas, maka jawaban tentang pernyataan "Kemampuan Mahasiswa untuk beradaptasi dengan lingkungan”, responden yang menjawab Cukup Baik sebanyak 2 orang (3,8\%), sebanyak 4 orang menjawab Baik (7,7\%), 20 orang menjawab Lebih baik (38,5\%), 20 orang menjawaab Istimewa (38,5\%) dan 6 orang $(11,5 \%)$ menjawab Sangat Istimewa.

\section{Keterampilan dalam Menjalankan Tugas}

Jawaban responden tentang pernyataan "Keterampilan dalam Menjalankan Tugas”, yang meliputi: Kesesuaian dengan instrukti, Kualitas hasil pekerjaan, Ketepatan waktu dan Kemampuan memecahkan masalah, dapat dilihat pada Tabel 3 di bawah ini:

Tabel 3. Keterampilan Mahasiswa dalam Menjalankan Tugas

\begin{tabular}{lll}
\hline Kategori & Jumlah n=52 & Persentase \\
\hline Baik & 1 & 1,9 \\
Lebih dari & 23 & 44,2 \\
Baik & & \\
Istimewa & 24 & 46,2 \\
$\begin{array}{l}\text { Sangat } \\
\text { Istimewa }\end{array}$ & 4 & 7,7 \\
Jumlah & 52 & 100 \\
\hline
\end{tabular}

Berdasarkan Tabel 3 dapat dilihat, jawaban tentang pernyataan "Keterampilan Mahasiswa dalam Menjalankan Tugas”, responden yang menjawab Baik sebanyak
1 orang (7,7\%), 23 orang menjawab Lebih baik (44,2\%), 24 orang menjawaab Istimewa (46,2\%) dan 4 orang $(7,7 \%)$ menjawab Sangat Istimewa.

\section{Tanggung Jawab Terhadap Tugas}

Adapun jawaban responden tentang pernyataan "Tanggung jawab mahasiswa terhadap Tugas”, dapat dilihat pada Tabel 4 di bawah ini:

Tabel 4. Tanggung Jawab MahasiswaTerhadap Tugas

\begin{tabular}{lll}
\hline Kategori & Jumlah $\mathrm{n}=52$ & Persentase \\
\hline Baik & 1 & 1,9 \\
Lebih dari & 20 & 38,5 \\
Baik & & \\
Istimewa & 25 & 48,1 \\
$\begin{array}{l}\text { Sangat } \\
\text { Istimewa }\end{array}$ & 6 & 11,5 \\
Jumlah & 52 & 100 \\
\hline
\end{tabular}

Berdasarkan Tabel 4 dapat dilihat, jawaban tentang pernyataan "Tanggung Jawab mahasiswa terhadap Tugas”, responden yang menjawab Baik sebanyak 1 orang (1,9\%), 23 orang menjawab Lebih baik (44,2\%), 24 orang menjawab Istimewa $(46,2 \%)$ dan 4 orang $(7,7 \%)$ menjawab Sangat Istimewa.

\section{Inisiatif dan Kreativitas}

Untuk pernyataan "Inisiatif dan Kreativitas”,jawaban responden dapat dilihat pada Tabel 5 di bawah ini:

Tabel 5. Inisiatif dan Kreativitas Mahasiswa

\begin{tabular}{lll}
\hline Kategori & Jumlah $\mathrm{n}=52$ & Persentase \\
\hline Cukup Baik & 1 & 1,9 \\
Baik & 5 & 9,6 \\
Lebih dari & 27 & 51,9 \\
Baik & & \\
Istimewa & 16 & 30,8 \\
Sangat & 3 & 5,8 \\
Istimewa & & \\
Jumlah & 52 & 100 \\
\hline
\end{tabular}

Pada Tabel 5 dapat dilihat, jawaban tentang pernyataan "Inisiatif dan Kreatifitas Mahasiswa ”, responden yang menjawab Cukup Baik ada 1 orang (1,9\%), yang menjawab Baik sebanyak 5 orang $(9,6 \%), 27$ orang $(51,9 \%)$ 
menjawab Lebih baik, 16 orang (30,8\%) menjawab Istimewa, 3 orang $(5,8 \%)$ menjawab Sangat Istimewa.

\section{Komunikasi}

Pernyataan responden tentang Kemampuan Komunikasi mahasiswa yang meliputi: Bekerja dalam kelompok (Kerja sama), Hubungan dengan atasan, Hubungan dengan rekan kerja, Hubungan dengan bawahan serta Hubungan dengan relasi, terlihat pada Tabel 6. di bawah ini: Tabel 6. Kemampuan Komunikasi Mahasiswa

\begin{tabular}{lll}
\hline Kategori & Jumlah n=52 & Persentase \\
\hline Cukup Baik & 1 & 1,9 \\
Baik & 2 & 3,8 \\
Lebih dari & 24 & 46,2 \\
Baik & & \\
Istimewa & 22 & 42,3 \\
Sangat & 3 & 5,8 \\
Istimewa & & \\
Jumlah & 52 & 100 \\
\hline
\end{tabular}

Berdasarkan Tabel 6 dapat dilihat, jawaban responden tentang pernyataan "Kemampuan Komunikasi Mahasiswa", memberikan pernyataan Cukup Baik sebanyak 1 orang (1,9\%), pernyataan Baik sebanyak 2 orang (3,8\%), 24 orang menjawab Lebih dari Baik (46,2\%), 22 orang(46,2\%) menjawab Istimewa dan 3 orang $(5,8 \%)$ menjawab Sangat Istimewa.

\section{Kedisiplinan}

Untuk pernyataan tentang “Kedisiplinan”, responden menjawab seperti yang terlihat pada Tabel 7. Tabel 7. Kedisiplinan Mahasiswa Selama PKL

\begin{tabular}{lll}
\hline Kategori & Jumlah $\mathrm{n}=52$ & Persentase \\
\hline Cukup Baik & 2 & 3,8 \\
Baik & 1 & 1,9 \\
Lebih dari & 22 & 42,3 \\
Baik & & \\
Istimewa & 22 & 42,3 \\
Sangat & 5 & 9,6 \\
Istimewa & & \\
Jumlah & 52 & 100
\end{tabular}

Pada Tabel 7 dapat dilihat, jawaban responden tentang "Kedisiplinan", memberikan pernyataan Cukup Baik sebanyak 2 orang (3,8\%), pernyataan Baik sebanyak 1 orang $(1,9 \%), 22$ orang menjawab Lebih dari Baik (42,3\%), 22 orang(42,3\%) menjawab Istimewa dan 5 orang $(9,6 \%)$ menjawab Sangat Istimewa.

\section{Kemandirian}

Pendapat responden tentang kemandirian mahasiswa, dapat dilihat pada Tabel 8 di bawah ini:

Tabel 8. Kemandirian Mahasiswa Dalam

Bekerja

\begin{tabular}{lll}
\hline Kategori & Jumlah n=52 & Persentase \\
\hline Cukup Baik & 1 & 1,9 \\
Baik & 1 & 1,9 \\
Lebih dari & 25 & 42,3 \\
$\begin{array}{l}\text { Baik } \\
\text { Istimewa }\end{array}$ & 22 & 42,3 \\
$\begin{array}{l}\text { Sangat } \\
\text { Istimewa }\end{array}$ & 3 & 9,6 \\
Jumlah & 52 & 100 \\
\hline
\end{tabular}

Melihat Tabel 8 di atas, maka responden memberikan pernyataan tentang "Kemandirian" mahasiswa sebagai berikut: 1 orang (1,9\%) menyatakan Cukup Baik, 1 orang (1,9\%) menyatakan Baik, 25 orang (42,3\%) memberikan pernyataan Lebih dari Baik, 22 orang (42,3\%) memberikan pernyataan Istimewa dan 3 orang $(9,6 \%)$ menyatakan Sangat Istimewa

\section{Sikap Potensial}

Responden memberikan pernyataan tentang "Sikap Potensial” mahasiswa yang meliputi: Sikap menghadapi pekerjaan, Disiplin kerja, Loyalitas/Kesetiaan, Semangat/Motivasi kerja dan Penampilan, dapat dilihat pada Tabel 9 di bawah ini:

Tabel 9. Sikap Potensial yang Dimiliki Mahasiswa

\begin{tabular}{lll}
\hline Kategori & Jumlah $\mathrm{n}=52$ & Persentase \\
\hline Baik & 2 & 3,8 \\
Lebih dari & 21 & 40,4 \\
$\begin{array}{l}\text { Baik } \\
\text { Istimewa }\end{array}$ & 25 & 48,1 \\
$\begin{array}{l}\text { Sangat } \\
\text { Istimewa }\end{array}$ & 4 & 7,7 \\
Jumlah & 52 & 100 \\
\hline
\end{tabular}

Berdasarkan Tabel 9 dapat dilihat, jawaban responden tentang pernyataan 
"Sikap Potensial yang Dimiliki Mahasiswa”, memberikan pernyataan Baik sebanyak 2 orang (3,8\%), menjawab Lebih dari Baik 21 orang (40,4\%), 25 orang(48,1\%) menjawab Istimewa dan 4 orang $(7,7 \%)$ menjawab Sangat Istimewa.

\section{KESIMPULAN DAN SARAN \\ Kesimpulan}

Kesimpulan dari hasil penelitian ini dapat dilihat sebagai berikut:

1. Kemampuan Mahasiswa untuk Beradaptasi Terhadap Lingkungan dalam kategori Sangat Istimewa 6 orang mahasiswa dengan Persentase $11,2 \%$

2. Inisiatif dan Kreatifitas Mahasiswa Terhadap Lingkungan Perusahaan dalam kategori Sangat Istimewa 3 orang dengan Persentase 5.8\%

3. Kemampuan Komunikasi mahasiswa yang meliputi, Bekerja dalam kelompok (Kerja sama), Hubungan dengan atasan, Hubungan dengan rekan kerja, Hubungan dengan bawahan serta Hubungan dengan relasi kategori sangat istimewa 3 orang

4. Sikap Potensial mahasiswa yang meliputi Sikap menghadapi pekerjaan, Disiplin kerja, Loyalitas/Kesetiaan,

Semangat/Motivasi kerja dan Penampilan dalam kategori sangat istimewa sekitar 4 orang mahasiwa

5. Keterampilan dalam Menjalankan Tugas yang meliputi Kesesuaian dengan instrukti, Kualitas hasil pekerjaan, Ketepatan waktu dan Kemampuan memecahkan masalah yang kategori sangat istimewa 4 orang mahasiswa

6. Kedisiplinan dan Kemandirian mashasiwa terhadap lingkungan perushaan dalam kategori sangat istimewa adalah 5 orang mahasiswa

\section{Saran}

Penulis akan memberikan saran terhadap hasil penelitian ini adalah:

Dalam program Job Training ini perlunya Mahasiswa meningkatkan Kemampuan beradaptasi dan Kemampuan menjalankan Tugas dalam Perusahaan dengan baik terutama dalam kategori sangat istimewa .

\section{DAFTAR PUSTAKA}

Mulyasa E. 2003. Kurikulum Berbasis Kompetensi. Konsep, Karakteristik dan Implementasi, Bandung.. Penerbit Remaja Rosdakarya.

Pulungan $\quad 1998$ Approaches,Methods and Techniques. Medan . Percetakan Peter Suraida Pengaruh Kompetensi Terhadap Kinerja Pegawai. Jurnal Sosiohumaniora Vol 17 No 3, November 2005

Surjati Jun. Jurnal Pendidikan. Volume 7 No 2, September 2008 Wallace Spring Jennifer.1992. English for Corporate Communication. United States of Amerika - REGENT PRENTICE HALL 